\title{
Assessment of Social Vulnerability of Households to Floods in Niger State, Nigeria
}

\author{
Jude Nwafor Eze ${ }^{1, a^{*}}$, Coleen Vogel ${ }^{2, b}$ and Philip Audu Ibrahim ${ }^{1, c}$ \\ ${ }^{1}$ Farming System Research Programme, National Cereals Research Institute, Badeggi, P.M.B 8, \\ Niger State, Nigeria. \\ ${ }^{2}$ School of Geography and Environmental Studies, University of the Witwatersrand, No 1 Jan \\ Smuts Avenue. P. Bag 3, 2050, Johannesburg, South Africa

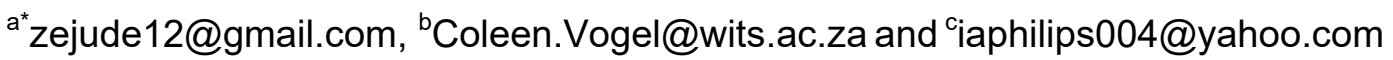

\section{Keywords: Vulnerability; adaptation; floods; poverty}

\begin{abstract}
Flood is known to cause devastating livelihood impacts, suffering and economic damages. To reduce the impact of floods, it is very important to identify and understand the socioeconomic factors that determine people's ability to cope with stress or change. Consequently, the study assesses the social vulnerability of the households to floods in Niger State, in order to provide the empirical evidence necessary for flood adaptation policies and strategies in the state. The data for the research were obtained from the household survey and Dartmouth Flood Observatory. The data obtained were analysed using descriptive and statistical analysis. The results show that flood events in the study area were caused by heavy rainfall, compounded by the opening of the Shiroro dam gate to release the excess flood in the reservoir. Moreover, results of Student " $t$ " test and OneWay Analysis of Variance on socio-economic characteristics show that households' major economic activities, educational status, household size, income distribution, and membership of cooperative society were significant at $\mathrm{p}<0.05$. Since the household respondents who depend primarily on farming, do not have formal education, family size $>10$, do not belong to cooperative society and earn less that N21000 per month have higher mean frequency, thus, the predominant households were, therefore, farmers, illiterate, have large family size, poor, and have no access to loan. Thus, the socio-economic characteristics of the households in the study area contribute to their vulnerability to floods by reducing their coping capacity. Based on the results of the assessment, it is recommended that measures are taken to mainstream flood adaptation (livelihood diversification through finance and technical assistance like loans and capacity building) into the development process.
\end{abstract}

\section{Introduction}

Flood is described as a natural hydrological extreme event affecting the flow regime of all rivers, particularly during the rainy season. Flood is defined as the temporary overflow of a river onto the adjacent lands not normally covered by water [1]. Thus, this study defines flood as an accumulation of too much water that overflows its bank particularly areas which are not usually inundated. Flooding, mostly in river floodplains, is as natural as rain and has been occurring for millions of years. Fertile floodplains such as the Mississippi Valley in the American Midwest, the Nile River valley in Egypt, and the Tigris-Euphrates in the Middle East have supported agriculture for millennia because of annual flooding which has left millions of tons of nutrientrich silt deposits behind [2]. However, flood sometimes is known to cause devastating livelihood impacts, suffering and economic damages. Most flood destruction is attributable to human activities particularly the desire to live near attractive coastlines and in river valleys/floodplains [3]. Landfilling and building on wetland and floodplain exacerbate flooding [3]. Moreover, overflow of a river due to a dam-breaks, prolonged seasonal rainfall, snowmelt, etc., also causes flooding [4]. It could also be caused by the intrusion of seawater onto coast lands during cyclonic/tidal surges [5]. When a river overflows its banks or the sea moves inland, structures poorly equipped to withstand the strength of water are easily destroyed [6]. 
In the United States, despite the availability of advanced flood mitigation and prediction, floods damage property worth about $\$ 6$ billion and kill about 140 people every year [7]. Samir [8] shows that the coastal flooding alone damages property worth about $\$ 3$ trillion worldwide. In China, millions of people have perished in floods during the last century from the Yellow River valley. In East Africa, the flood of 1998, for example, impacted on agriculture and livelihoods [9]. Also, the flood from tropical cyclones in Mozambique that occurred in 2000 caused considerable damage to property and infrastructure [10]. The Mozambique flood reduced the annual growth rate from $8 \%$ to $2 \%$ [10] and displaced 2 million people [9].

In Nigeria, several river floods have occurred such as the Cross River Basin flood of 1970, the Lower Ogun River Basin annual flood and the River Ogunpa flood in Oyo State [11]. Iyanda, [12] documented flood occurrences along the River Niger, in 1964, 1988, 1994, 1998 and 1999 that were all devastating. Moreover, the Sokoto flood in 2010, Ibadan flood in 2011, Lagos flood in 2011, and the 2012 floods in parts of Lokoja, Makurdi, Asaba, Ogbaru, and Yenegoa, had shown that flooding is one of the major environmental problems faced in Nigeria [5]. Consequently, when floodwaters recede, affected areas are often blanketed in silt and mud [13]. In addition, residents of flooded areas can be left without power and clean drinking water, leading to outbreaks of deadly waterborne diseases like typhoid, hepatitis A, and cholera [14]. Thus, floods have far-reaching adverse impacts on human health, food security, economic activity, physical infrastructure, natural resources and the environment [15]. The exposure to flooding is due to a range of socio-economic factors, such as income, occupation, information technology, access to loan facilities, etc. [16]. In different parts of the world, these factors vary from place to place to form uneven varieties of vulnerability [17].

The Vulnerability is defined as a set of socio-economic factors that determine people's ability to cope with stress or change [18]. The vulnerability is described as something that exists within systems independently of external hazards. Thus, in many human systems, socio-economic vulnerability is viewed as an inherent property of a system arising from its internal characteristics [19]. Social vulnerability is determined by factors such as poverty and inequality, marginalization, food entitlements, access to insurance and housing quality [19]. It is the social vulnerability that has been the primary focus of field research and vulnerability mapping projects, which are generally concerned with identifying the most vulnerable members of society and examining variations in vulnerability between or within districts that may experience similar hazards [20]. In this formulation, it is the interaction of hazard with the socioeconomic vulnerability that produces an outcome, generally measured in terms of physical or economic damage or human mortality and morbidity [21]. The nature of socio-economic vulnerability will depend on the nature of the hazard to which the human system in question is exposed [22]. Although socioeconomic vulnerability is not a function of hazard, a certain attribute of a given system will make it more vulnerable to a particular type of hazard than to other [22]. For example, livelihood diversification, sustainable agricultural practices, afforestation will be important determinants of a community's (socioeconomic) vulnerability to floods and desertification but is less likely to influence its vulnerability to an earthquake. Although socioeconomic vulnerability is not a function of hazard, it is, to a certain extent at least, hazard-specific [23].

Studies on vulnerability to floods have been undertaken in various parts of the world [23-29, $5,6]$. Majority of the studies concentrated on the impacts of floods on agriculture, health, coastal zones, and forestry while some concentrated on the causes of flooding. Little or no work has been done on the social vulnerability of the household to flooding, in Niger State, which has much to offer in terms of policy decisions. Policies on flood adaptation in Nigeria, particularly Niger State have often been made without experimental foundations placed on the structural factors that make human societies and communities susceptible to damage from external hazards such as floods. Against this background, the research assesses the social vulnerability of the households to floods in Niger State. This is to identify the socioeconomic characteristics of households in the study area as a background to highlight its implications on the household vulnerability to floods. The research also underlines the need to come up with options to reduce the impacts of floods and how to integrate these options into the State government development process. 


\section{Materials and Methods}

\subsection{Study Area}

Niger State is one of the 36 states in Nigeria. The State has a tropical climate and belongs to the tropical wet and dry (AW) of the Koppen climatic classification, with annual rainfall varying between $1100 \mathrm{~mm}$ in the north to $1600 \mathrm{~mm}$ in the southern part of the state [30]. The region experiences two distinct seasons, the dry and wet seasons. The duration of the rainy season ranges from 150 to 210 days from the north to the south [30]. Mean maximum temperature remains relatively high throughout the year, averaging about $32^{\circ} \mathrm{C}$, particularly in March and June. The lowest minimum temperature occurs usually between December and January [31]. The landscape consists mostly of wooded savannas and includes the floodplains of the Kaduna River [31]. Most of the inhabitants are engaged in farming. Maize, rice, yam, and groundnuts are cultivated both for export and for domestic consumption [31]. Cattle, goats, sheep, chickens, and guinea fowl are raised for meat.

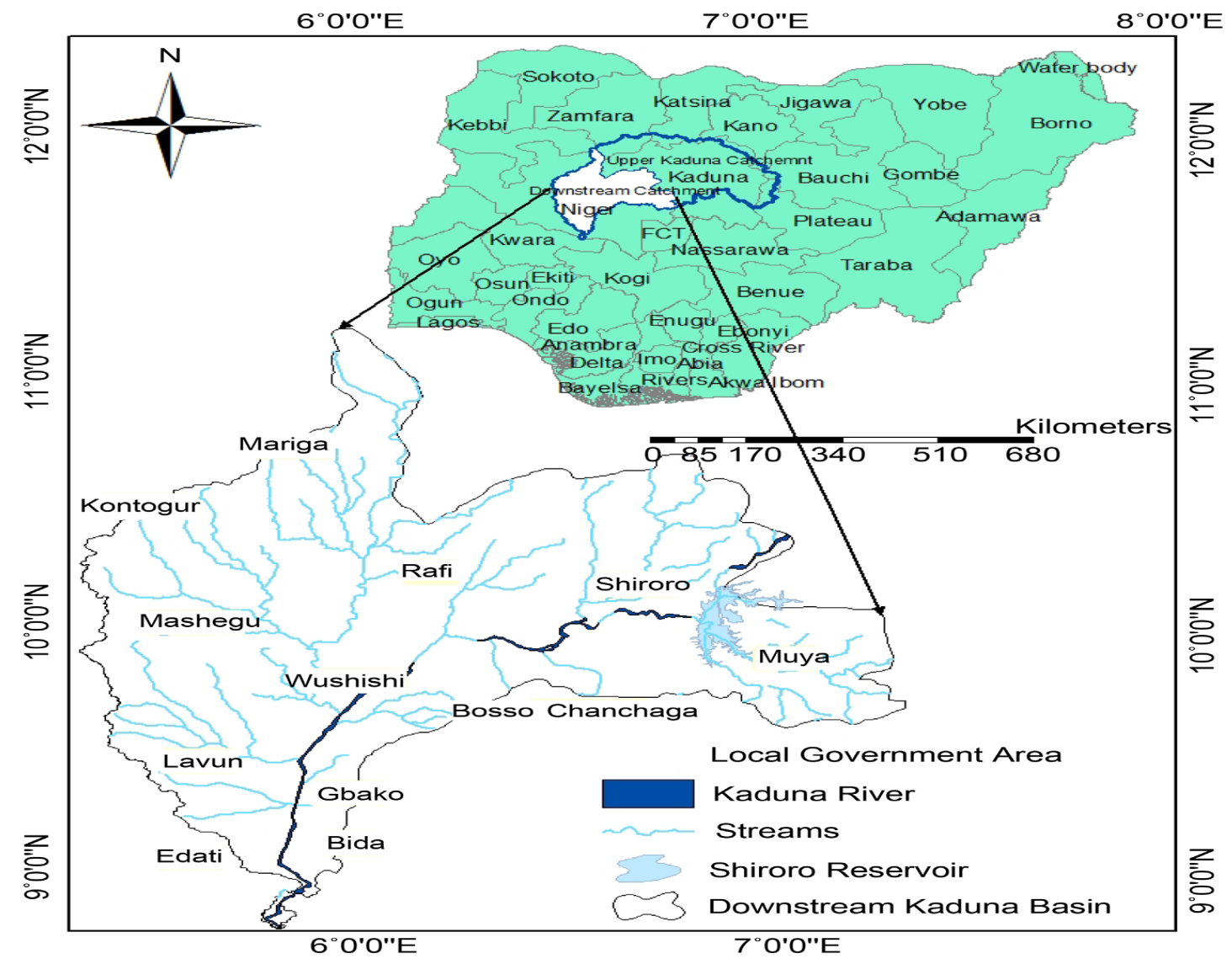

Figure 1. Map of the study area showing the downstream communities along the Kaduna River basin in Niger State (adapted from Chinwendu [6])

\subsection{Study Design}

The study adopted the survey design. The studied population consists of 176,460 households in the study area. According to Yamane [32], the sampling size of any population that is more than 100,000 persons is 400 using:

$$
n=N / 1+N\left(e^{2}\right)
$$

at 0.05 level of precision: where $n$ is the sample size; $N$ is the population, that is, census population figure; and $e$ is the level of precision/sampling error. Since the population of the study area is more than 100,000, therefore, 400 questionnaires were administered. The questionnaires administered per Local Government Area (LGA) were calculated using the equation as shown below:

$$
(\mathrm{N} 1 / \mathrm{N} 2) \times 400
$$


where N1 is the population of an LGA, N2 is the population of the study area and 400 is the sample size of the study area. The result is shown in Table 1. Based on the nature of the communities/environment and target population in the study area, purposive sampling technique was employed to select the communities and households interviewed. A Social Vulnerability Assessment Approach was employed to explore the fundamental aspect of household vulnerability and adaptation to floods in Niger State. Data on the educational status, household size, economic activities of the households, membership of households in cooperative societies and monthly income distribution of the respondents were collected to determine the extent of social vulnerability of the households to floods in the study area. Data on floods were collected from Dartmouth Flood Observatory to establish flood occurrences in the study area.

Table 1. Sample Size of the Respondents per LGAs in the Study Area

\begin{tabular}{ccc}
\hline $\begin{array}{c}\text { Local Govt } \\
\text { Area }\end{array}$ & $\begin{array}{c}\text { Number of Households } \\
\text { per LGA }\end{array}$ & $\begin{array}{c}\text { Sample Size of } \\
\text { Respondents per } \\
\text { LGA }\end{array}$ \\
\hline Muya & 20,047 & 45 \\
Shiroro & 44,092 & 99 \\
Wushishi & 15,507 & 35 \\
Gbako & 24,555 & 57 \\
Edati & 31,619 & 72 \\
Lavun & 40,640 & 92 \\
Total & 176,460 & 400 \\
\hline
\end{tabular}

Source: National Population Commission 2006

\subsection{Data Analysis}

The data collected were analysed using descriptive statistics (percentages and frequencies) and statistical analyses (Student ' $\mathrm{T}$ ' test, and One Way Analysis of Variance) were employed. Hypotheses $\left(\mathrm{H}_{\mathrm{o}}\right.$ and $\left.\mathrm{H}_{1}\right)$ therefore, were formulated and tested. The analyses were carried out using Statistical Package for Social Sciences (SPSS) version 21 and Microsoft Excel.

In our study, Student ' $T$ ' test is used to determine whether or not the differences between two sample means are sufficiently great as to justify a conclusion that the means of their population also differ significantly. Thus, Student ' $T$ ' tests were carried out to determine whether or not the mean differences between the respondents that have formal education and those who do not have formal education; and also on respondents that belong to co-operative society and those who do not belong to any co-operative were sufficiently significant. To establish a conclusion, hypotheses are posited, thus:

$H_{0}$ : There is no significant difference in the number of respondents who have formal education and those who do not have formal education in the study area

$H_{1}$ : There is a significant difference in the number of respondents who have formal education and those who do not have formal education. Other factors tested followed the same sequence.

On the other hand, one-way Analysis of Variance was used because we compared the means of three or more sample distributions [33]. It consists of obtaining two independent estimates of variance, one based on the viability between samples (between sample variance or between sample sum of squares) and the other based upon viability within samples [34]. The analysis of variance used the F-test which is the ratio of two or more variances (ratio between mean variance to within mean-variance). The estimated F-ratio is compared with the theoretical value in the F-table at a specific degree of freedom and level of significance. Thus, Household monthly income, household size, and economic activities and membership of co-operative society were collected, in order to determine the predominant household income class, household size, access to loan and major economic activity of the population in the study area. Hypotheses, therefore, were formulated and tested using one-way Analysis of Variance. 
$H_{0}$ : There is no significant difference in the household monthly income; household size distribution, and major economic activity among the households in the study area.

$H_{1}$ : There is a significant difference in the household monthly income distribution; household size and major economic activity among the households in the study area.

In the construction of frequency distribution tables, Norcliffe [35] method was used to determine the number of classes.

$$
\mathrm{K}=\sqrt{ } \mathrm{N}
$$

where $\mathrm{K}$ is the number of classes and $\mathrm{N}$ is the variables; $\mathrm{N}$ is the number of LGAs which is 6 . Also, a qualitative analysis of the in-depth interview was carried out to understand in greater details the socio-economic factors that make certain households living along Kaduna river basin particularly vulnerable to floods, what limits them from adapting to floods and the adaptation strategies used in the study area.

\section{Result}

\subsection{Some of the Significant Flood Events on the Communities along the Kaduna River at Shiroro Local Government Area of Niger State}

Table 2 shows that the Kaduna River primarily overflowed its bank as a result of heavy rainfall. However, the immediate cause (secondary cause) was identified to be as a result of the opening of Shiroro, hydroelectric dam to release excess water accumulated due to heavy rainfall. The years 1995, 1999, 2003, 2007, 2010, 2012, 2016 flood events were attributed to the opening of the dam gates to release the excess water in the reservoir as a result of heavy rainfall. The floods mainly occurred between August and September. The Severity Class of the entire flood events so far along the Kaduna River is class 1 type. This means that the magnitude assessment (the flood magnitude value is a measure of "how severe" a flood is, as a strictly hydrological occurrence) shows large flood events that have significant damage to structures or agriculture with some records of fatalities. To calculate the flood magnitude, total runoff volumes are measured for the flood hydrograph above the bankfull discharge, using as this threshold discharge the $1.5 \mathrm{y}$ recurrence interval flow. The reported current magnitude value is the runoff volume accumulated so far, compared to the flood volume of record, times 10.

Table 2. Significant flood events that occurred down the Shiroro dam on the Kaduna River

\begin{tabular}{|c|c|c|c|c|c|}
\hline $\begin{array}{l}\text { Date of flood } \\
\text { occurrence }\end{array}$ & Primary causes & Secondary causes & $\begin{array}{c}\text { Farmlands } \\
\text { affected }(\mathrm{sq} \mathrm{km})\end{array}$ & $\begin{array}{c}\text { Flood } \\
\text { magnitude }\end{array}$ & Severity \\
\hline September 1988 & Heavy rainfall & Heavy rainfall & 684 & 6.9 & 1 \\
\hline August 1995 & Heavy rainfall & $\begin{array}{l}\text { hydroelectric dam } \\
\text { opened }\end{array}$ & 973 & 4.7 & 1 \\
\hline September 1999 & Heavy rainfall & $\begin{array}{l}\text { hydroelectric dam } \\
\text { opened }\end{array}$ & 1105 & 5.6 & 1 \\
\hline August 2003 & Heavy rainfall & $\begin{array}{l}\text { hydroelectric dam } \\
\text { opened }\end{array}$ & 946 & 6.9 & 1 \\
\hline July 2006 & Heavy rainfall & Not available & 103 & 3.1 & 1 \\
\hline August, 2007 & Heavy rainfall & $\begin{array}{l}\text { hydroelectric dam } \\
\text { opened }\end{array}$ & 863 & 7.7 & 1 \\
\hline September 2010 & Heavy rainfall & Not available & 678 & 7.1 & 1 \\
\hline September, 2012 & Heavy rainfall & $\begin{array}{l}\text { hydroelectric dam } \\
\text { opened }\end{array}$ & 1913 & 8.2 & 1 \\
\hline September 2016 & Heavy rainfall & $\begin{array}{l}\text { hydroelectric dam } \\
\text { opened }\end{array}$ & 1300 & 6.8 & 1 \\
\hline
\end{tabular}

Source: Adapted from the Dartmouth Flood Observatory (www.dartmouth.edu) 


\subsection{Socio-Economic Stresses Increasing Vulnerability to Floods in Niger State, Nigeria}

\subsubsection{Educational Status of the Household Respondents in the Study Area}

Table 3 reveals that only $30 \%$ of the respondents have formal education, while $70 \%$ of the respondents have no formal education. This implies that majority of respondents in the study area have no formal education. Formal education refers to an organized education model, structured and administered according to a given set of laws and norms, presenting a rather rigid curriculum as regards objectives, content and methodology [36].

Table 3. Educational Status of the Respondents

\begin{tabular}{|c|c|c|}
\hline $\begin{array}{l}\text { Local Govt } \\
\text { Area }\end{array}$ & $\begin{array}{l}\text { Number of Household } \\
\text { respondents without } \\
\text { formal education }\end{array}$ & $\begin{array}{l}\text { Number of Household respondents } \\
\text { with formal education }\end{array}$ \\
\hline Muya & 31 & 14 \\
\hline Shiroro & 65 & 34 \\
\hline Wushishi & 26 & 9 \\
\hline Gbako & 38 & 19 \\
\hline Edati & 55 & 17 \\
\hline Lavun & 65 & 27 \\
\hline Total & $(70 \%)$ & $(30 \%)$ \\
\hline Mean & 46.7 & 20 \\
\hline
\end{tabular}

Source: Fieldwork 2017

Formal learning is normally delivered by trained teachers in a systematic way within a school /college/institute or university [36]. Therefore, any education obtained outside the above defined formal education is classified as "no formal education" in this work.

On the other hand, the result of the Student ' $\mathrm{T}$ ' tests shows that, the $t$-value is 3.34966. The $p$-value is .003685 . The result is significant at $p<0.05$. Therefore, $\mathrm{H}_{\mathrm{o}}$ is rejected and $\mathrm{H}_{1}$ is accepted. So, there is a significant difference in the number of those who have formal education and those who do not have formal education. Since the respondents who do not have formal education have the higher mean frequency (Table 3). This implies that the predominant population in the study area do not have formal education.

\subsubsection{Household Size of the Respondents in the Study Area}

Table 4 shows that household sizes in the study area were grouped into three, according to Norcliffe [35] method of classification, namely 1-5, 6-10, 11 \& above with $14 \%, 26 \%$ and $60 \%$ of the total respondents respectively. The result indicates that the third group $(11 \&$ above $)$ with more than 10 persons per household has the highest number of respondents. Thus, $60 \%$ of the respondents in the study area have more than 10 persons per household.

Table 4. Household Size of the Respondents in the Study Area

\begin{tabular}{cccc}
\hline LGAs & $1-5$ & $6-10$ & $11 \&$ above \\
\hline Muya & 4 & 13 & 28 \\
Shiroro & 13 & 20 & 66 \\
Wushishi & 6 & 9 & 20 \\
Gbako & 7 & 16 & 34 \\
Edati & 12 & 21 & 39 \\
Lavu & 13 & 26 & 53 \\
Total & 55 & 105 & 230 \\
$\%$ & $14 \%$ & $26 \%$ & $60 \%$ \\
\hline
\end{tabular}

Source: Fieldwork 2017 
The analysis of variance of the household size distribution of respondents shows an F-ratio of 13.5452 and P-value of 0.000436 (Table 5). Since the F-ratio is greater than the P-value at 0.05 level of significance, $\mathrm{H}_{\mathrm{o}}$ was rejected and $\mathrm{H}_{1}$ was accepted. Thus, there is a statistically significant difference in the household size distribution in the study area. This implies that the class of household size with higher mean values were predominant in the study area. Therefore, the class of household with more than 10 persons per household predominates in the study area.

Table 5. Analysis of Variance of the household size distribution of respondents in the study area

\begin{tabular}{cccccc}
\hline $\begin{array}{c}\text { Source of } \\
\text { variation }\end{array}$ & $\begin{array}{c}\text { Sum of } \\
\text { squares }\end{array}$ & $\begin{array}{c}\text { Degree of } \\
\text { Freedom (Df) }\end{array}$ & $\begin{array}{c}\text { Mean sum } \\
\text { of squares }\end{array}$ & F-ratio & P-value \\
\hline $\begin{array}{c}\text { Between } \\
\text { groups }\end{array}$ & 3052.7778 & 2 & 1354.1667 & $\mathrm{~F}=$ & 0.000436 \\
$\begin{array}{l}\text { Within } \\
\text { groups } \\
\text { Total }\end{array}$ & 1690.3333 & 15 & 83.5778 & & \\
\hline
\end{tabular}

Source: Fieldwork 2017

\subsubsection{Economic Activities of the Households in the Study Area}

The result shows that $75 \%$ of the total household respondents were involved in farming as their major source of income. However, $25 \%$ of the total population was involved in non-farming activities such as trading (7\%), civil service (6\%), artisan (4\%) and fishing (8\%) (Table 6).

Table 6. Major Economic Activities of the Respondents in the Study Area

\begin{tabular}{lccccc}
\hline LGA's & Farming & Trading & $\begin{array}{l}\text { Civil } \\
\text { Service }\end{array}$ & Artisan & Fishing \\
\hline Muya & 36 & 2 & 2 & 1 & 4 \\
Shiroro & 65 & 11 & 8 & 5 & 10 \\
Wushishi & 28 & 3 & 1 & 0 & 3 \\
Gbako & 46 & 4 & 2 & 1 & 4 \\
Edati & 56 & 3 & 4 & 5 & 4 \\
Lavun & 72 & 5 & 6 & 4 & 5 \\
Total & $303(75 \%)$ & $28(7 \%)$ & $23(6 \%)$ & $16(4 \%)$ & $30(8 \%)$ \\
$\%$ & 50.5 & 4.7 & 3.8 & 2.7 & 5 \\
\hline
\end{tabular}

Source: Fieldwork 2017

The analysis of variance of economic activities of respondents shows that F-ratio is 40.8777 and P-value of 0.0001 (Table 7). Since the F-ratio is greater than the P-value at 0.05 level of significance. $\mathrm{H}_{\mathrm{o}}$ was rejected and $\mathrm{H}_{1}$ was accepted. Thus, there is a statistically significant difference in the household economic activities in the study area. This implies that the economic activity with higher mean values is the predominant in the study area. Therefore, farming with the mean value of 50.5 is the predominant economic activities of the households in the study area.

Table 7. Analysis of Variance of major Economic Activities of the Respondents in the Study Area

\begin{tabular}{cccccc}
\hline $\begin{array}{c}\text { Source of } \\
\text { variation }\end{array}$ & $\begin{array}{c}\text { Sum of } \\
\text { squares }\end{array}$ & $\begin{array}{c}\text { Degree of } \\
\text { Freedom (Df) }\end{array}$ & $\begin{array}{c}\text { Mean sum } \\
\text { of squares }\end{array}$ & F-ratio & P-value \\
\hline $\begin{array}{c}\text { Between } \\
\text { groups }\end{array}$ & 10379.6667 & 4 & 2594.9167 & $\mathrm{~F}=$ & 0.00001 \\
$\begin{array}{l}\text { Within } \\
\text { groups }\end{array}$ & 1587 & 25 & 63.48 & & \\
$\quad$ Total & 11966.6667 & 29 & & & \\
\hline Source: Fieldwork 2017 & & & &
\end{tabular}




\subsubsection{Household Monthly Income Distribution}

The result of the household monthly income distribution shows that $71.5 \%$ of the respondents belong to the income class that earn between N5,000-N20,000 per month, $19 \%$ earn between $\mathrm{N} 21,000-\mathrm{N} 36,000$ and $9.5 \%$ earn N37,000 and above (Table 8)

Table 8. Household Monthly Income Distribution in the Study Area

\begin{tabular}{cccc}
\hline LGAs & $\begin{array}{c}\text { N5000- } \\
\text { N20000 }\end{array}$ & $\begin{array}{c}\text { N21000- } \\
\text { N36000 }\end{array}$ & $\begin{array}{c}\text { N37000 \& } \\
\text { above }\end{array}$ \\
\hline Muya & 28 & 12 & 5 \\
Shiroro & 67 & 3 & 2 \\
Wushishi & 24 & 8 & 3 \\
Gbako & 41 & 4 & 7 \\
Edati & 56 & 14 & 3 \\
Lavun & 69 & 16 & 7 \\
Total & $285(71.5 \%)$ & $77(19 \%)$ & $39(9.5 \%)$ \\
Mean & 47.5 & 12.8 & 6.5 \\
\hline Source: Fieldwork 2017 & &
\end{tabular}

The analysis of variance of monthly income distribution of respondents produced an F-ratio of 24.20131 and the P-value of 0.00002 (Table 9). Since the calculated F-ratio is greater than the P-value at 0.05 level of significance, $\mathrm{H}_{0}$ was rejected and $\mathrm{H}_{1}$ was accepted. Thus, there is a statistically significant difference in the household monthly income distribution of respondents in the study area.

Table 9. Analysis of Variance of Household's Monthly Income Distribution of the Study Area

\begin{tabular}{cccccc}
\hline $\begin{array}{c}\text { Source of } \\
\text { variation }\end{array}$ & $\begin{array}{c}\text { Sum of } \\
\text { squares }\end{array}$ & $\begin{array}{c}\text { Degree of } \\
\text { Freedom (Df) }\end{array}$ & $\begin{array}{c}\text { Mean sum } \\
\text { of squares }\end{array}$ & F-ratio & P-value \\
\hline $\begin{array}{c}\text { Between } \\
\text { groups }\end{array}$ & 6636 & 2 & 3318 & 24.20131 & 0.00002 \\
$\begin{array}{l}\text { Within } \\
\text { groups }\end{array}$ & 2056.5 & 15 & 137.1 & & \\
Total & 8692.5 & 17 & & & \\
\hline
\end{tabular}

Source: Fieldwork 2017

This implies that the income class with higher mean values were the predominant population in the study area. Table 8 shows that the households that earn between N5000 \& N20,000 per month have the highest mean value of 47.5. Poverty was measured using the United Nations poverty line, which says that anybody who earns less than $\$ 1$ /day is considered poor. $(\$ 1=\mathrm{N} 450 \times$ 30 days $=$ N13, 500 per head as at the time of data collection. Thus a household with 2 persons will need to earn $(13,500 \times 2=\mathrm{N} 27000)$.

\subsubsection{Membership of Respondents in Co-Operative Societies in the Study Area}

The result of membership in co-operative societies indicates that $72 \%$ of the respondents were not members of any co-operative society, while $28 \%$ of the respondents belong to a co-operative society (Table 10). 
Table 10. Membership of Respondents in Co-operative Societies in the Study Area

\begin{tabular}{ccccccc}
\hline LGAs & $\begin{array}{c}\text { Farmer's } \\
\text { Co-op. }\end{array}$ & $\begin{array}{c}\text { Workers } \\
\text { Co-op }\end{array}$ & $\begin{array}{c}\text { Traders } \\
\text { Co-op }\end{array}$ & $\begin{array}{c}\text { Religious } \\
\text { Co-op }\end{array}$ & $\begin{array}{c}\text { Friends } \\
\text { Co-op }\end{array}$ & $\begin{array}{c}\text { Non- } \\
\text { Member }\end{array}$ \\
\hline Muya & 5 & 2 & 1 & 1 & 2 & 34 \\
Shiroro & 20 & 2 & 2 & 5 & 7 & 63 \\
Wushishi & 6 & 0 & 0 & 1 & 1 & 27 \\
Gbako & 10 & 3 & 1 & 3 & 1 & 39 \\
Edati & 7 & 3 & 2 & 3 & 5 & 52 \\
Lavun & 12 & 2 & 1 & 2 & 1 & 74 \\
Total & $60(15 \%)$ & $12(3 \%)$ & $7(2 \%)$ & $15(3.8 \%)$ & $17(4.2 \%)$ & $289(72 \%)$ \\
& 10 & 2 & 1.2 & 2.5 & 2.8 & 48.2 \\
\hline
\end{tabular}

Source: Fieldwork 2017

On the other hand, the result of the T-test shows that the t-value $=3.53715$, the $\mathrm{p}$-value $=0.002691$. The result is, therefore, significant at $\mathrm{p}<0.05$. Consequently, $\mathrm{H}_{\mathrm{o}}$ is rejected and $\mathrm{H}_{1}$ is accepted. Thus, there is a significant difference in the number of respondents who belong to a co-operative society and those who do not belong to any co-operative society. Since the respondents who do not belong to any co-operative society has the higher mean frequency (Table 10), it implies that the predominant population in the study area do not belong to any co-operative society.

\section{Discussion}

Flood events in the study area were caused by heavy rainfall, compounded by the opening of the Shiroro dam gate to release the excess flood in the reservoir. Consequently, the release of the excess water from the reservoir has forced thousands of households out of their homes. The flood event of the year 1988 occurred before the Shiroro dam started its operation in 1990, which was caused by heavy rainfall. The Shiroro dam, therefore, makes the floodwater accumulate. Upon release, the magnitude of the flood flow into the surrounding communities on the floodplain becomes high, causing greater damages to houses, farmlands and leads to loss of lives. However, the households in the study area were predominantly dependent on farming activities. Moreover, the respondents that depend primarily on non-farming activities such as trading, civil service, artisan and fishing activities were also involved in farming. In-depth interviews with the key informants show that farming activities in the study area were greatly affected by frequent floods. [23] argue that flood is one of the principal hazards associated with climate variability and changes that affect farming activities. Therefore, the households that depend primarily on farming will be particularly at risk from flood hazard [37]. Farming is, therefore, currently being constrained in Nigeria particularly Niger State by climate variability and extremes [23, 38].

Moreover, the household monthly income distributions of the respondents in the study area were predominantly low-income earners (the poor) with very low membership in the co-operative society. Several studies such as [39-43] have identified the poor as the population groups most likely to experience the adverse effects of climate change and other natural hazards. In addition, the educational status of the households indicates that the predominant population in the study area were illiterate. This was attributed to the parents' apathy towards child-education. Most parents do not send their children to school, but take them along to farms. Farming activities in the study area were being carried out by the fathers and the children, which occupy most of their time daily. Consequently, daily farming activities by most households leave the children with little or no time for schooling. Simon and co-authors[44] argue that the high illiteracy rate in a community may translates into unsustainable land use practices by rejecting some modern technologies, such as the use of fertilizers, improved crop varieties, agro-forestry, modern farming implements and methods. Consequently, unsustainable land use practices increase environmental degradation, which exposes the land to negative impacts of floods. Since the predominant households in the study area were; 
dependent on farming, low-income earners, illiterate, and have large household size, with low access to insurance, the households in the study area have a high social vulnerability to floods and low adaptive capacity to cope with the flood impacts.

\section{Recommendations}

1. Resettlement of households living on the River Kaduna floodplain will prevent the flood risks.

2. Warning the downstream communities before opening the dam gate will also reduce the flood impacts

3. Monetary Compensation of Flood Victims: A compensation system should be established by the Niger State government to support the victims of flood disasters to restore their economic basis and their living conditions in due time. This would also help in alleviating non-insurable public damage.

4. Use of improved crop varieties: Early maturing crops will enable farmers to cultivate and harvest within a short period before the flood in August/September, while flood-resistant crops should be adopted. The new improved crop varieties enhance the reduction of climate change impacts on farmers.

5. Livelihood diversification: Creating economic activities that will generate employment is needed to reduce the impact of floods on the households. These could be achieved through finance and technical assistance such as loans and capacity building. When finance and technical assistance are given to the households, it could motivate them to venture into small and medium scale businesses such as poultry farming, fish farming, production of local briquettes (to solve the immediate farmers' problems of unaffordable fuel), trades and services, which on its own will generate employment

\section{Conclusions}

The socio-economic characteristics identified in the study area have exacerbated the vulnerability of the households living in the Kaduna River basin to floods in Niger State. The predominant households were low-income earners, depends on farming, illiterate, have large family size, and do not have access to a loan. Thus, the socio-economic characteristics of the households in the study area contribute highly to their vulnerability to floods by reducing their coping capacity. Moreover, failures in harvest, therefore, will certainly undermine future household food security, thereby increasing their vulnerability to malnutrition. Finally, the study has effectively used socioeconomic characteristics of households to determine the extent of their social vulnerability to floods, which has much to offer in terms of policy decisions. The results can be used for the reduction of potential damage of floods and the vulnerability of households by integrating its outputs into spatial planning and emergency planning on reducing the impact of floods in Niger State, Nigeria.

\section{Conflict of Interest}

The authors declare that there is no conflict of interest.

\section{Acknowledgement}

We would like to thank Prof. A.O Nyong, Geography and Regional Planning, University of Jos, Nigeria for his guidance and helpful comments on the draft of this research. 


\section{References}

[1] N. Middleton, An Introduction to Environmental Issues: The Global Casino, New York, 2003, pp. 366-372.

[2] S. Rufat et al., Social vulnerability to floods: review of case studies and implications for measurement, International Journal of Disaster Risk Reduction. 14(4) (2015) 470-486.

[3] A.M.S. Ali, September 2004 flood event in South Western Bangladesh: A study of its nature, causes, and human perception and adjustments to a new hazard, Natural Hazards. 40 (2007) 89-111.

[4] J.N. Eze, Vulnerability and Adaptation to Climate Variability and Extremes: A Case Study of Flooding in Niger State, Nigeria, M.Sc. Thesis, University of the Witwatersrand, Johannesburg, 2006.

[5] T.I. Akukwu, C. Ogbodo, Spatial Analysis of Vulnerability to Flooding in Port Harcourt Metropolis, Nigeria, SAGE. 5(1) (2015) 1-9.

[6] O.G. Chinwendu et al., Households vulnerability and adaptation to climate variability induced water stress on downstream Kaduna River Basin, American Journal of Climate Change. 6 (2017) 247-267.

[7] M.A. Hula, J.C. Udoh, An assessment of the impact of flood events in Makurdi, Nigeria, Civil and Environmental Research. 7(10) (2015) 53-60.

[8] K.C. Samir, Community vulnerability to floods and landslides in Nepal, Ecology and Society. 18(1) (2013) 8 .

[9] IPCC, Climate change 2001: Impact, Adaptability and Vulnerability contribution of working II to the third Assessment Report of the Inter-governmental Panel on climate change, Geneva; UNEP/WMO, 2001.

[10] C. Vogel, Seven fat years and seven lean years? Climate Change and Agriculture in Africa, IDS III Bulletin, Institute of Development Studies. 36(2) (2005).

[11] I.O. Adelekan, Vulnerability assessment of an urban flood in Nigeria: Abeokuta flood 2007, Natural Hazards. 56 (2010) 215-231.

[12] I.A. Iyanda, River Niger Flood and Flood Management for sustainable Hydroelectric Power Generation at Kainji Dam, Unpublished MSc Research, Federal University of Technology, Minna, 2003

[13] S. Mukhopadhyay, A geo-environmental assessment of flood dynamics in lower Ajoy River inducing sand splay problem in Eastern India, Ethiopian Journal of Environmental Studies and Management. 3(2) (2010) 1-15.

[14] T.E. Ologunorisa, M.J. Abawua, Flood risk assessment: A review, Journal of Applied Sciences \& Environmental Management. 9(1) (2005) 57-63.

[15] S. Hajat et al., The human health consequences of flooding in Europe and the implications for public health: a review of the evidence, Appl. Environ. Sci. Public Health. 1 (2003) 13-21.

[16] E. Lisa, F. Schipper, Climate Change Adaptation and Development: Exploring the linkages, Tyndall Center, Working Paper No.107, 2009.

[17] B. Smit, T. Wandel, Adaptation, adaptive capacity and vulnerability, Global Environmental Change. 16(3) (2008) 282-292.

[18] K. Allen, Vulnerability Reduction and the Community-Based Approach: A Philippines Study, in: M. Pelling (Ed.), Natural Disasters and Development in a Globalizing World, New York: Routledge, 2003, pp. 170-184. 
[19] W.N. Adger, M. Kelly, Social vulnerability to climate change and the architecture of entitlements, Mitigation and Adaptation Strategies for Global Change. 4 (1999) 253-266.

[20] K. O'Brien et al., Mapping Vulnerability to Multiple Stressors: Climate Change and Globalization in India, Global Environmental Change. 14(4) (2004) 303-313.

[21] W.N. Adger et al., New indicators of vulnerability and adaptive capacity, Tyndall Centre for Climate Change Research, Technical Report 7 1-46, 2004.

[22] W.N. Adger, Social Vulnerability to Climate Change and Extremes in Coastal Vietnam, World Development. 27(2) (1999) 249-269.

[23] J.N. Eze et al., Analysis of Farmers' Vulnerability to Climate Change in Niger State, Nigeria, International Letters of Social and Humanistic Sciences. 82 (2018) 1-9.

[24] S. Kumar, Santosh, Flood Risk Zoning of Satluj River Basin, Himachal Pradesh, India, International Letters of Natural Sciences. 40 (2015) 6-15.

[25] G. Bankoff, Constructing vulnerability: The historical, natural and social generation of flooding in metropolitan Manila, Disasters. 27 (2003) 224-238.

[26] R. Few, Flooding, vulnerability and coping strategies: Local responses to a global threat, Progress in Development Studies. 3 (2003) 43-58.

[27] M.I.M. Kaleel, Land Degradation Analysis on Coastal Area of Ampara District, International Letters of Natural Sciences. 53 (2016) 80-86.

[28] J.H. Diaz, The Public Health Impact of Hurricanes and major Flooding, J. La State Med. Soc.156(3) (2004) 145-150.

[29] J.S. Lee, H.I Choi, Comparison of Flood Vulnerability Assessments to Climate Change by Construction Frameworks for a Composite Indicator, Sustainability. 10 (2018) 768.

[30] B.J. Garnier, Weather conditions in Nigeria. Climatological Research Series, No.2. McGill University, Montreal, Canada, 1967.

[31] N.P. Iloeje, A new geography of Nigeria, Lagos, Longman, Nigeria Limited, 1982.

[32] T. Yamane, Statistics: An introductory analysis (2nd ed.), New York, NY: Harper and Row, 1967.

[33] R.N.C. Anyadike, Statistical Methods for the Social and Environmental Sciences, Spectrum, Ibadan, 2007.

[34] P.E. Udofia, Educational of Social Sciences Statistics, Immaculate Pub. Ltd, 2006.

[35] G.B. Norcliffe, Inferential Statistics for Geographers, London, 1977.

[36] ADEA, Diversifying Education Delivery System. Reviving Discourse on the Formal//Nonformal Interface. Report of the Workshop on Non-formal education, Gabrone, Botswana, 2013, pp. 23-26.

[37] S Devereux, J. Edwards, Climate Change and food Security, IDS III Bulletin, Institute of Development Studies. 35(3) (2004).

[38] S.A. Tiamiyu et al., Rainfall Variability and Its Effect on Yield of Rice in Nigeria, International Letters of Natural Sciences. 49 (2015) 63-68.

[39] P.M. Mbithi, B.M. Wisner, Drought and Famine in Kenya. Magitude and attempted solutions, Journal of Eastern African Research and Development. 3 (1973) 113-143.

[40] C.M. Kamau et al., Case studies of Drought Impacts and Responses in Central and Eastern Kenya, in: T.E. Downing, K.W.Gitu, C.M. Kamau (Eds.), Coping with drought in Kenya. National and local strategies, Boulder and London, 1989, pp. 211- 230. 
[41] T. Reardon, P. Matlon, Seasonal Food Insecurity and Vulnerability in Drought Affected Regions of Burkina Faso, in: D.E. Sahn, (Ed), Seasonal variability in third world agriculture. The consequences for food security, Baltimore: International Food Policy Research Institute/John Hopkins University press, 1989, pp. 118-136.

[42] FEWSNET, Annual Performance and Monitoring Report for the year 2000. Famine Early Warning System Network (FEWSNET), Chemonics International Inc. Washington DC. 2000. www.fews.net/resources/gcontent/pdf/1000053.pdf.

[43] FIVIMS, Report on Geniver meeting on vulnerability. Fifth meeting of the subgroup on indicators, assessment and mapping, Geniva from 10-11 July 2000. Food Insecurity and vulnerability Information and Mapping System (FIVIMS), Rome. 2000.

[44] B.P. Simon, A. Garba, G.M. Bunu, Determinants of sustainable agricultural and management practices among arable crop farmers in Northern part of Taraba State, Nigeria, Journal of Science and Technology. 3(7) (2013). 